\title{
Silage intake and milk production in cows given barley or barley fibre with or without dried distillers solubles
}

\author{
HANNELE ALA-SEPPÄLÄ, PEKKA HUHTANEN and MATTI NÄSI \\ Department of Animal Husbandry, University of Helsinki \\ SF-00710 Helsinki, Finland
}

\begin{abstract}
Twenty Friesian cows in four pens were arranged in a $4 \times 4$ Latin Square with a $2 \times 2$ factorial arrangement of treatments to evaluate the effect of barley fibre with solubles and dried distillers solubles (DDS) as a protein supplement on silage intake and milk production. Each experimental period lasted $4 \mathrm{wk}$, during which the cows were given ad libitum silage with one of the four supplements: barley (B), barley + DDS (BD), barley fibre (F) and barley fibre + DDS (FD). All the supplements were given at the rate of $7.5 \mathrm{~kg} /$ day on dry matter (DM) basis. In cows given DDS, $0.9 \mathrm{~kg}$ of barley or barley fibre was replaced by DDS on DM basis. The principal carbohydrate constituent of the B supplement was starch and of the F supplement hemicellulose.

Silage DM intake was $0.38 \mathrm{~kg} /$ day $(\mathrm{P}<0.05)$ higher for cows given $\mathrm{F}$ diets but the total $\mathrm{DM}$ intake was not significantly affected by the diet given.

Milk yield was $2.2 \mathrm{~kg} /$ day $(\mathrm{P}<0.001)$ higher in cows given $\mathrm{F}$ diets than $\mathrm{B}$ diets. But milk fat content was lower $(\mathrm{P}<0.001)$, and as a result milk fat yield was slightly higher $(805 \mathrm{v} .787$ $\mathrm{g} /$ day), with $\mathrm{B}$ diets. $\mathrm{F}$ diets were also associated with a lower $(\mathrm{P}<0.05)$ protein concentration in milk, but because of the higher yield, milk protein yield was $8.3 \%(\mathrm{P}<0.001)$ higher than in $\mathrm{B}$ diets. Feeding $\mathrm{F}$ diets increased milk lactose content $(\mathrm{P}<0.05)$ and lactose yield $(\mathrm{P}<0.001)$ relative to $\mathrm{B}$ diets. Live weight gain was higher $(\mathrm{P}<0.05)$ for cows given $\mathrm{B}$ diets.

DDS supplementation had no significant effect on feed intake, milk production or milk composition. Cows given DDS increased their live weight less $(\mathrm{P}<0.01)$ than those fed without DDS.

Despite the smaller amount of ME available for production, milk energy yield was higher $(\mathrm{P}<0.05)$ in cows given $\mathrm{F}$ diets, indicating a shift in energy partioning towards milk instead of body tissues. Estimates of the efficiency of utilization of ME for milk production were higher for cows given $\mathrm{F}$ diets than for those given $\mathrm{B}$ diets both including and ignoring live weight change in the calculations.

The results show that barley fibre with solubles, despite a lower digestibility than barley, can produce more milk and protein and a similar yieid of milk fat provided that silage is given ad libitum.
\end{abstract}

Index words: barley, barley fibre, distillers solubles, silage, milk production 


\section{Introduction}

In the previous study, replacing barley by increasing amounts of barley fibre increased silage intake at the two highest levels of barley fibre inclusion, but this effect was largely compensated by reduced intake of supplement of barley fibre inclusion (HUHTANEN et al. 1988). Milk yield was not affected by the level of barley fibre in the diet, although organic matter digestibility was reduced markedly. This indicates that cows given barley fibre diets partitioned a greater proportion of the metabolizable energy available for production to milk and less to body tissues than those given barley.

In several studies protein supplements (eg. soybean meal, fish meal) have increased milk yield in cows given grass silage based diets. Responses in milk yield can be attributed in large part to improved dry matter (DM) digestibility and increased DM intake (OLdHAM 1984). In Finland rapeseed meal is currently the most important protein supplement in dairy concentrates. Supplementation of silage and cereal grain diets with rapeseed meal has resulted in increased milk yield (SETẢLÄ et al. 1984). Other protein supplements, barley protein and dried distillers solubles (DDS), are now available from integrated ethanol-starch production (NÄsı 1988). The annual production will be soon about 10 million $\mathrm{kg}$. Replacing soybean meal by barley protein resulted in lower $\mathrm{N}$ retention in young cattle and had no effect relative to the basal diet of hay and barley (HuHTANEN and NÄsı 1988, unpublished). On the other hand, according to KLOPFENSTEIN (1985), distillers.solubles contain nutrients that stimulate rumen microbial activity, possibly providing branched chain fatty acids, especially in cattle on low quality forage diets.
The present study was planned to examine the effects on feed intake and milk production of barley fibre with solubles as a supplement to silage based diet. To improve the palatability, barley molasses was added to the barley fibre. Further, the effects of DDS as protein supplement and the interaction between the composition of energy supplement and the DDS inclusion were examined.

\section{Material and methods}

\section{Animals and management}

The experiment was conducted using 20 lactating Friesian cows. On the average, the cows had calved 3.4 (SE 0.7) times and 110 days (SE 6) before the start of the experiment. The animals were held in a loose-housing barn divided into four pens of five cows. The 20 cows were allocated into five blocks according to their milk yield and calving date and then from each block were allocated at random to the four pens. Silage was given ad libitum for each pen and concentrates were given individually in the milking parlour twice daily.

\section{Design and treatments}

The experimental design was a $4 \times 4$ Latin Square with $2 \times 2$ factorial arrangement of treatments. The four experimental diets consisted of grass silage ad libitum and one of the supplementary feeds: barley (B), barley + dried distiller's solubles (DDS) (BD), barley fibre (F) and barley fibre + DDS (FD). All the supplements were given at the rate of $7.5 \mathrm{~kg}$ dry matter (DM)/d. On diets BD and FD $0.9 \mathrm{~kg}$ of barley or barley fibre DM was 
replaced by DDS. No attempt was made to balance the higher crude protein and lower energy content of barley fibre than of barley in the formulation of the diets. All the concentrate ingredients and the mineral mixture $(250 \mathrm{~g} / \mathrm{d})$ were weighed separately and mixed. Barley fibre, obtained by sieving the cell wall material of barley endosperm, was pressed mechanically by screw press for dewatering and dried with a drum and combined to barley molasses. DDS was received after distillation of the non-fermentables of B-starch by evaporation and drying with a spraydryer (NÄsı 1988). The silage was made from timothy, meadow fescue and red clover sward. The grass was cut with a disc mower and harvested with a precisionchop forage harvester after a wilting period of about $4 \mathrm{~h}$. The grass was ensiled into bunker silos of 250 tonnes and preserved with a formic acid additive $(800 \mathrm{~g} / \mathrm{l})$ used at the rate of $4-5 \mathrm{l} / \mathrm{t}$.

Milk yield and concentrate intake were recorded individually daily and silage intake was recorded for each pen. After milking, any concentrate refusals were removed and weighed. Silage refusals were removed and weighed once daily before the afternoon feeding.

Each experimental period lasted 28 days, of which the first 14 days served as an adjustment period for the cows to adapt to the new dietary treatment and data collection was made in the last 14 days. The cows were changed to a new dietary treatment within four days.

Live weights were determined at biweekly intervals before the afternoon feeding on two consecutive days. Live weight was calculated as a linear regression of time and live weight.

\section{Sampling and analyses}

Silage was sampled once a week during the first 14 days and twice a week during the last 14 days of each period and analysed for DM and $\mathrm{pH}$. Samples of two weeks were composit- ed for other analyses. The ingredients of concentrate were sampled once a week, analysed for DM and then composited into a sample for two periods. This sample was used for chemical analyses and calculation of feeding values as described by HUHTANEN et al. (1988). Chemical composition of the experimental feeds is presented in Table 1.

Milk samples were collected at both milkings for two consecutive days at the end of the 3 rd and 4th week of each experimental period. Each sample was analysed for fat, protein and lactose content with an infrared milk analyser.

\section{Calculation of results and statistical analyses}

The dietary ME concentrations were used to calculate ME intake. Milk energy was calculated from equations of TYRrEL and REID (1965). ME requirements for maintenance and live weight change were calculated according to the Ministry of Agriculture Food and Fisheries (1975). ME available for milk production was calculated as the difference between ME intake and ME requirements for maintenance and live weight change.

Statistical analyses were based on the data of the last 14 days of each period except for live weight change. The data were subjected to analyses of variance for Latin Square experiments. In all the analyses the data from one pen in a single period were used as an experimental unit and 6 degrees of freedom remained for the residual. The sum of squares of the treatment effect was further partitioned into effects due to differences between barley and barley fibre (B v. F), into effects of DDS supplementation and into differences resulting from interaction between concentrate energy source and DDS supplement (SNEDECOR and Cochran 1967). Because the responses to DDS were similar when it was given with barley and with barley fibre, the significance of the interaction effect is not shown in tables. 
Table 1. Chemical composition of experimental feeds $(\mathrm{g} / \mathrm{kg} \mathrm{DM})$ and estimated feed values.

\begin{tabular}{|c|c|c|c|c|}
\hline & Silage & Barley & Fibre & DDS \\
\hline Dry matter $(\mathrm{g} / \mathrm{kg})$ & 228 & 885 & 923 & 933 \\
\hline \multicolumn{5}{|l|}{ In dry matter } \\
\hline Ash & 89 & 24 & 49 & 179 \\
\hline Crude protein & 137 & 140 & 186 & 327 \\
\hline Ether extract & 47 & 34 & 72 & 62 \\
\hline Crude fibre & 302 & 46 & 102 & 31 \\
\hline $\mathrm{NFE}^{\prime}$ & 417 & 755 & 592 & 401 \\
\hline NDF & 509 & 179 & 409 & 43 \\
\hline ADF & 314 & 40 & 102 & 10 \\
\hline ADL & 24 & 0 & 7 & 0 \\
\hline Cellulose & 290 & 40 & 95 & 10 \\
\hline Hemicellulose & 195 & 139 & 307 & 33 \\
\hline Starch & nd. & 583 & 186 & 35 \\
\hline Sugar & 51 & 40 & 59 & 39 \\
\hline \multicolumn{5}{|l|}{ Feed values } \\
\hline $\mathrm{FFU}^{2} / \mathrm{kg} \mathrm{DM}$ & 0.692 & 1.177 & 0.979 & 0.982 \\
\hline $\mathrm{ME} \mathrm{MJ/kg} \mathrm{DM}$ & 9.75 & 13.75 & 11.76 & 11.61 \\
\hline$D^{2} P^{3} \mathrm{~g} / \mathrm{kg} \mathrm{DM}$ & 93 & 105 & 145 & 271 \\
\hline
\end{tabular}

nd. $=$ not determined. ${ }^{1} \mathrm{NFE}=$ nitrogen free extracts, ${ }^{2} \mathrm{FFU}=$ fattening feed unit $=0.7 \mathrm{~kg}$ starch, ${ }^{3} \mathrm{DCP}=$ digestible crude protein. In silage: $\mathrm{pH} 3.86$; in dry matter $(\mathrm{g} / \mathrm{kg})$ : sugars 51 , lactic acid 68 , acetic acid 24 , propionic acid 0.5 , butyric acid 2.1 , isovaleric acid 0.16 , valeric acid 0.68 ; in total nitrogen $(\mathrm{g} / \mathrm{kg}): \mathrm{NH}_{3}-\mathrm{N} 60$, soluble $\mathrm{N} 514$; D-value 0.609 .

\section{Results}

\section{Feed intake}

The effects of concentrate energy source and DDS on feed intake and the estimated nutrient consumption are shown in Table 2. The difference in silage DM intake was $0.38 \mathrm{~kg}$ $(\mathrm{P}<0.05)$ in favour of $\mathrm{F}$ diets. No differences in the total DM intake were observed because the cows given $\mathrm{F}$ diets refused to eat all the supplement. Inclusion of DDS in the diets did not affect silage or total DM intake. Because the differences in DM intake were small the changes in estimated nutrient consumption only reflect changes in chemical composition and feeding values of the feeds. FFU and ME intake were higher $(\mathrm{P}<0.001)$ for cows given $\mathrm{B}$ diets than those given $\mathrm{F}$ diets. Dietary inclusion of DDS increased $(\mathrm{P}<0.001) \mathrm{DCP}$ intake and also cows given $\mathrm{F}$ diets received more $(\mathrm{P}<0.001)$ DCP.

Intakes of the different dietary constituents are shown in Table 3. Replacing barley by barley fibre in the diet increased intakes of cell wall carbohydrates and reduced starch intake.

\section{Milk yield and milk composition}

The cows given $\mathrm{F}$ diets yielded, on average, $2.2 \mathrm{~kg}(\mathrm{P}<0.001)$ more milk than those given B diets (Table 4). Dietary inclusion of DDS had no significant effect on milk yield or milk composition. No significant interactions between the energy source of the supplement and DDS inclusion were observed in the production response but there was a trend for the response to be better with barley fibre than with barley (barley fibre, $+0.6 \mathrm{~kg}$ v. barley -0.3 $\mathrm{kg}$ /day).

The concentration of milk fat was significantly $(\mathrm{P}<0.001)$ higher with $\mathrm{B}$ diets than with $\mathrm{F}$ diets, resulting in an equal daily production of milk fat. Milk protein content was slightly $(32.1$ v. $31.5 \mathrm{~g} / \mathrm{kg})$ but significantly $(\mathrm{P}<0.05)$ higher when $\mathrm{B}$ diets were given. Because the differences in milk protein content were relatively small, the changes in milk protein yield mainly reflected changes in milk yield being higher $(\mathrm{P}<0.001)$ in cows given $\mathrm{F}$ diets than in those given $\mathrm{B}$ diets. The protein to fat ratio was much higher for $\mathrm{F}$ diets than for $\mathrm{B}$ diets $(0.91$ v. $0.82 ; \mathrm{P}<0.001)$. 
Table 2. The effect of dietary treatments on feed intake $(\mathrm{kg} / \mathrm{DM} / \mathrm{d})$ and nutrient consumption in cows given grass silage ad libitum.

\begin{tabular}{|c|c|c|c|c|c|c|c|}
\hline & \multicolumn{4}{|c|}{ Treatment } & \multirow[t]{2}{*}{$\begin{array}{c}\text { SEM } \\
6 \mathrm{df} \\
(\mathrm{n}=20)\end{array}$} & \multicolumn{2}{|c|}{$\begin{array}{l}\text { Statistical } \\
\text { significance } \\
\text { of effect }\end{array}$} \\
\hline & B & BD & F & FD & & $\begin{array}{c}\text { B v. } \\
\text { F }\end{array}$ & $\begin{array}{c}\text { Effect } \\
\text { of DDS }\end{array}$ \\
\hline Grass silage & 10.27 & 10.44 & 10.60 & 10.86 & 0.14 & * & NS \\
\hline Barley & 7.32 & 6.30 & - & - & & & \\
\hline Fibre & - & - & 6.99 & 6.09 & & & \\
\hline DDS & - & 0.89 & - & 0.88 & & & \\
\hline Concentrate total & 7.32 & 7.19 & 6.99 & 6.96 & & & \\
\hline Total DM intake & 17.59 & 17.62 & 17.59 & 17.82 & 0.08 & NS & NS \\
\hline $\begin{array}{l}\text { DM intake as \% } \\
\text { of live weight }\end{array}$ & 2.82 & 2.83 & 2.83 & 2.86 & 0.008 & NS & * \\
\hline $\begin{array}{l}\text { DM intake as } \\
\mathrm{g} / \mathrm{kg} \mathrm{W} \mathrm{W}^{0.75}\end{array}$ & 140.8 & 141.2 & 141.0 & 142.6 & 0.42 & NS & NS \\
\hline FFU/d & 15.77 & 15.55 & 14.22 & 14.37 & 0.05 & $* * *$ & NS \\
\hline $\mathrm{ME} \mathrm{MJ/d}$ & 201.6 & 199.4 & 186.2 & 188.1 & 0.68 & $* * *$ & NS \\
\hline DCP g/d & 1750 & 1900 & 2022 & 2146 & 10.5 & $* * *$ & $* * *$ \\
\hline
\end{tabular}

SEM $=$ standard error of means

Significance: NS (non-significant), ${ }^{*}(\mathrm{P}<0.05),{ }^{* *}(\mathrm{P}<0.01),{ }^{* * *}(\mathrm{P}<0.001)$

Table 3. Daily intake $(\mathrm{kg})$ of crude protein, ether extract, starch, crude fibre, NFE, NDF, ADF, cellulose and hemicellulose.

\begin{tabular}{|c|c|c|c|c|c|c|c|}
\hline & \multicolumn{4}{|c|}{ Treatment } & \multirow[t]{2}{*}{$\begin{array}{c}\text { SEM } \\
6 \mathrm{df} \\
(\mathrm{n}=20)\end{array}$} & \multicolumn{2}{|c|}{$\begin{array}{l}\text { Statistical } \\
\text { significance } \\
\text { of effect }\end{array}$} \\
\hline & B & BD & $\mathrm{F}$ & $\mathrm{F}$ & & B v. & $\begin{array}{c}\text { Effect } \\
\text { of DDS }\end{array}$ \\
\hline Crude protein & 2.47 & 2.64 & 2.78 & 2.93 & 0.02 & $* * *$ & $* * *$ \\
\hline Ether extract & 0.73 & 0.76 & 1.00 & 1.00 & 0.01 & $* * *$ & NS \\
\hline Starch & 4.27 & 3.70 & 1.30 & 1.16 & 0.06 & $* * *$ & $* *$ \\
\hline Crude fibre & 3.43 & 3.46 & 3.90 & 3.91 & 0.04 & $* * *$ & NS \\
\hline NFE & 9.80 & 9.46 & 8.55 & 8.48 & 0.03 & $* * *$ & $* * *$ \\
\hline NDF & 6.53 & 6.47 & 8.25 & 8.05 & 0.08 & $* * *$ & NS \\
\hline ADF & 3.50 & 3.52 & 4.02 & 4.03 & 0.04 & $* * *$ & NS \\
\hline Cellulose & 3.27 & 3.28 & 3.73 & 3.73 & 0.04 & $* * *$ & NS \\
\hline Hemicellulose & 3.03 & 2.95 & 4.22 & 4.02 & 0.04 & $* * *$ & $*$ \\
\hline
\end{tabular}

For significance: see Table 2.

$\mathrm{F}$ diets were associated with a higher lactose content and lactose yield $(0.6 \mathrm{~g} / \mathrm{kg}, \mathrm{P}<0.05$; $123 \mathrm{~g} /$ day, $\mathrm{P}<0.001)$ than $\mathrm{B}$ diets.

Feeding $\mathrm{B}$ diets resulted in a higher $(\mathrm{P}<$ 0.05 ) daily live weight gain than $\mathrm{F}$ diets and dietary inclusion of DDS reduced significantly $(\mathrm{P}<0.01)$ live weight gain compared with cows fed without extra protein.

The efficiency of conversion of feed to milk expressed as FFU/kg FCM was better $(\mathrm{P}<$ 0.001 ) for cows offered $F$ diets than for those offered B diets. Cows given DDS consumed more $(\mathrm{P}<0.05) \mathrm{FFU} / \mathrm{kg}$ FCM than cows fed without protein supplement. 


\section{Energy utilization}

Calculations of energy utilization are shown in Table 5. Milk energy output was $2.4 \mathrm{MJ} /$ day $(\mathrm{P}<0.05)$ higher and the amount of ME available for milk production was $8.5 \mathrm{MJ} /$ day $(\mathrm{P}<0.01)$ smaller when $\mathrm{F}$ diets were given. The efficiency of transferring the surplus ME into milk $\left(\mathrm{k}_{1}\right)$ averaged 0.560 (SE 0.004) including live weight change and was significantly higher $(\mathrm{P}<0.01)$ with $\mathrm{F}$ diets than with $\mathrm{B}$ diets. Dietary inclusion of DDS resulted in lower $(\mathrm{P}<0.05) \mathrm{k}_{1}$ when live weight change was included, but no difference was observed ignoring live weight change.

\section{Discussion}

\section{The effect of DDS}

DDS supplements had no effect on silage intake, milk yield or milk composition. The lack of response to DDS may be related to the high degradability of DDS protein in the rumen. In growing cattle, replacing soybean meal progressively by barley protein, a byproduct from the same ethanol-starch process, reduced $\mathrm{N}$ retention from 32 to $28 \mathrm{~g}$ /day (HuHTANEN and NÄsı 1988). In addition, assuming degradability coefficients of 0.80 for silage and barley $\mathrm{N}$, the supply was of both rumen degradable $\mathrm{N}$ and rumen undegradable N calculated according to ARC (1984) were sufficient to meet the requirements of cows fed without DDS supplements. On the other hand, increases in silage intake and milk yield have been reported (eg. CASTLE et al. 1977, Gordon 1979, Thомas et al. 1981, KasSEM et al. 1987) when protein supplements of lower ruminal degradability were given with grass silage ad libitum.

\section{A comparison of barley and barley fibre}

The difference in the intake of supplements $\mathrm{B}$ and $\mathrm{F}$ was much smaller than in the previous experiment (HuHTANEN et al. 1988), indicating a favourable effect of barley solubles on palatability. The barley fibre used in the present study contained more crude protein and water soluble carbohydrates and less cell wall carbohydrates than the barley fibre used in the previous study. It should be noted that in the present study the supplements were offered during milking in the milking parlour.

The effect of the energy source of the supplement on silage DM intake was small $(0.38 \mathrm{~kg} / \mathrm{day})$, though significant. In the previous trial (HuHTANEN et al. 1988), increasing the proportion of barley fibre in the diet increased silage DM intake markedly but the effect was mainly offset by the reduced intake of supplement. Likewise, when small or moderate levels of concentrate have been used, the effect of concentrate energy source on silage DM intake has been relatively small (CAStle et al. 1981, Mayne and Gordon 1984, Sloan et al. 1987, Huhtanen 1987 a). On the other hand, Thоmas et al. (1986) reported that cows given high levels of supplement based on unmolassed sugar beet pulp and rice bran ate $0.9 \mathrm{~kg} /$ day more silage DM than those given barley based supplements. At high level of concentrate inclusion, forage DM intake was higher in cows given fibrous concentrates than in those given starchy concentrates (Phipps et al. 1987, Sutton et al. 1987), indicating that the energy source of the concentrate is more important at high levels of concentrate inclusion.

Similar, although smaller, increases in milk yield have been observed when barley was replaced by unmolassed sugar beet pulp and rice bran (Thомаs et al. 1986) or by unmolassed sugar beet pulp (HUHTANEN 1987 a). On the other hand, in many other studies (eg. CAStle et al. 1981, MAYNe and Gordon 1984, PhIPPS et al. 1987, SLOAN et al. 1987) no differences have been found between starchy and fibrous concentrates in their effect on milk yield.

The reasons for higher $(2.2 \mathrm{~kg} /$ day $)$ milk production in cows given $\mathrm{F}$ diets than in those given $\mathrm{B}$ diets are unclear. The effects of barley and barley fibre on milk yield cannot be accounted for by differences in feed intake or 
Table 4. The effect of dietary supplements on milk yield, milk composition and feed conversion in cows given grass silage ad libitum.

\begin{tabular}{|c|c|c|c|c|c|c|c|}
\hline & \multicolumn{4}{|c|}{ Treatment } & \multirow[t]{2}{*}{$\begin{array}{c}\text { SEM } \\
6 \mathrm{df} \\
(\mathrm{n}=20)\end{array}$} & \multicolumn{2}{|c|}{$\begin{array}{l}\text { Statistical } \\
\text { significance } \\
\text { of effect }\end{array}$} \\
\hline & B & $\mathrm{BD}$ & $\mathrm{F}$ & FD & & $\begin{array}{c}\text { B v. } \\
\text { F }\end{array}$ & $\begin{array}{c}\text { Effect } \\
\text { of DDS }\end{array}$ \\
\hline Milk yield (kg/d) & 21.0 & 20.7 & 22.7 & 23.3 & 0.34 & $* * *$ & NS \\
\hline $\mathrm{FCM}$ yield $(\mathrm{kg} / \mathrm{d})$ & 20.5 & 20.3 & 20.7 & 21.3 & 0.33 & NS & NS \\
\hline Fat yield (g/d) & 810 & 799 & 777 & 796 & 16 & NS & NS \\
\hline Protein yield $(\mathrm{g} / \mathrm{d})$ & 669 & 663 & 713 & 729 & 7.4 & $* * *$ & NS \\
\hline Lactose yield (g/d) & 1040 & 1030 & 1142 & 1173 & 19 & $* * *$ & NS \\
\hline $\begin{array}{l}\text { Milk composition } \\
\text { Fat }(\mathrm{g} / \mathrm{kg}) \\
\text { Protein }(\mathrm{g} / \mathrm{kg}) \\
\text { Protein } / \mathrm{fat} \\
\text { Lactose }(\mathrm{g} / \mathrm{kg})\end{array}$ & $\begin{array}{c}39.0 \\
32.0 \\
0.83 \\
49.6\end{array}$ & $\begin{array}{c}38.9 \\
32.1 \\
0.85 \\
49.7\end{array}$ & $\begin{array}{c}34.5 \\
31.6 \\
0.94 \\
50.2\end{array}$ & $\begin{array}{c}34.4 \\
31.4 \\
0.93 \\
50.3\end{array}$ & $\begin{array}{l}0.74 \\
0.23 \\
0.015 \\
0.19\end{array}$ & $\begin{array}{c}* * * \\
* \\
* * * \\
*\end{array}$ & $\begin{array}{l}\text { NS } \\
\text { NS } \\
\text { NS } \\
\text { NS }\end{array}$ \\
\hline $\begin{array}{l}\text { Live weight } \\
\text { Mean }(\mathrm{kg}) \\
\text { Change }(\mathrm{kg} / \mathrm{d})\end{array}$ & $\begin{array}{l}631 \\
0.56\end{array}$ & $\begin{array}{l}631 \\
0.18\end{array}$ & $\begin{array}{l}631 \\
0.35\end{array}$ & $\begin{array}{r}632 \\
0.07\end{array}$ & $\begin{array}{l}1.95 \\
0.06\end{array}$ & $\stackrel{\text { NS }}{*}$ & $\begin{array}{l}\text { NS } \\
* *\end{array}$ \\
\hline $\begin{array}{l}\text { Feed conversion } \\
\mathrm{FFU} / \mathrm{kg} \mathrm{FCM}^{\prime} \\
\mathrm{kg} \mathrm{DM} / \mathrm{kg} \mathrm{FCM} \\
\text { DCP g/kg FCM }{ }^{2}\end{array}$ & $\begin{array}{l}0.471 \\
0.871 \\
68.6\end{array}$ & $\begin{array}{l}0.513 \\
0.887 \\
77.9\end{array}$ & $\begin{array}{l}0.419 \\
0.861 \\
81.1\end{array}$ & $\begin{array}{l}0.441 \\
0.847 \\
84.4\end{array}$ & $\begin{array}{l}0.01 \\
0.02 \\
2.11\end{array}$ & $\begin{array}{l}* * * \\
\text { NS } \\
* *\end{array}$ & $\stackrel{*}{\text { NS }}+$ \\
\hline
\end{tabular}

' Production feed units intake corrected for maintenance and live weight change,

2 Production DCP intake corrected for maintenance.

For significance: see Table 2 .

Table 5. The effect of dietary treatments on calculated energy balance (MJ/day) and efficiency in cows given grass silage ad libitum.

\begin{tabular}{|c|c|c|c|c|c|c|c|}
\hline & \multicolumn{4}{|c|}{ Treatment } & \multirow[t]{2}{*}{$\begin{array}{c}\text { SEM } \\
6 \mathrm{df} \\
(\mathrm{n}=20)\end{array}$} & \multicolumn{2}{|c|}{$\begin{array}{l}\text { Statistical } \\
\text { significance } \\
\text { of effect }\end{array}$} \\
\hline & B & $\mathrm{BD}$ & $\mathrm{F}$ & FD & & $\begin{array}{c}\mathrm{B} v \text {. } \\
\mathrm{F}\end{array}$ & $\begin{array}{l}\text { Effect } \\
\text { of DDS }\end{array}$ \\
\hline ME intake & 201.6 & 199.4 & 186.2 & 188.1 & 0.68 & $* * *$ & NS \\
\hline $\begin{array}{l}\text { ME from change } \\
\text { of live weight }{ }^{1}\end{array}$ & -19.4 & -7.2 & -12.4 & -4.6 & 1.92 & $*$ & $* *$ \\
\hline $\begin{array}{l}\text { Energy output } \\
\text { Maintenance } \\
\text { Milk }\end{array}$ & $\begin{array}{l}65.7 \\
63.8\end{array}$ & $\begin{array}{l}65.8 \\
63.0\end{array}$ & $\begin{array}{l}65.7 \\
65.0\end{array}$ & $\begin{array}{l}65.8 \\
66.6\end{array}$ & $\begin{array}{l}0.18 \\
0.93\end{array}$ & $\begin{array}{c}\text { NS } \\
*\end{array}$ & $\begin{array}{l}\text { NS } \\
\text { NS }\end{array}$ \\
\hline $\begin{array}{l}\text { Efficiency } \\
\text { Including live } \\
\text { weight change } \\
\text { Ignoring live } \\
\text { weight change }\end{array}$ & $\begin{array}{l}0.556 \\
0.474\end{array}$ & $\begin{array}{l}0.502 \\
0.478\end{array}$ & $\begin{array}{l}0.608 \\
0.544\end{array}$ & 0.570 & 0.014 & $* *$ & NS \\
\hline
\end{tabular}

1 Allowing $28 \mathrm{MJ}$ for each kg lost and subtracting $34 \mathrm{MJ}$ for each kg gained.

For significance: see Table 2 . 
ME supply. The total DM intake was only $0.10 \mathrm{~kg} /$ day higher, while estimated ME intake was 13.4 MJ lower for cows given $\mathrm{F}$ diets. The digestibility of the diets was not determined in the present study, and the ME value for barley fibre was estimated using the digestibility coefficients determined in sheep (NÄsı 1988). Increasing the proportion of barley fibre without solubles in the diet caused a marked reduction in the digestibility of organic matter (HUHTANEN et al. 1988).

One possible explanation for the higher milk yield with $\mathrm{F}$ diets is higher dietary protein content ( $161 \mathrm{v} .145 \mathrm{~g} / \mathrm{kg} \mathrm{DM}$ ). This is not, however, supported by the effect of increasing dietary protein content by DDS inclusion, for DDS improved the milk yield when given with barley fibre $(+0.60 \mathrm{~kg} /$ day $)$ decreased it when given with barley $(-0.28 \mathrm{~kg} /$ day $)$.

Because the differences in milk yield are not satisfactorily explained by the factors discussed above, other points need to be considered. Replacing barley by barley fibre may have modified the nutrient supply to tissues, possibly through changing the proportions of individual fatty acids produced in the rumen. Silage-barley diets are associated with high protozoal numbers in the rumen (CHAMBERLAIN et al. 1985); and in animals given silage based diets the proportion of butyrate in rumen VFA increases with increased proportion of barley based concentrates in the diets (see HuhtANEN 1987 b). In intraruminal infusion studies, butyrate has consistently decreased milk yield (see Thomas and ChamberLain 1984). This possibility requires further investigation, but the concomitant changes in milk fat content strongly suggest changes in the rumen VFA pattern. The lower proportion of butyrate with sugar beet pulp than with barley (RoOke et al. 1987, Huhtanen 1988) also supports the hypothesis that fibrous by-products produce less butyrate than does barley in animals given silage based diets.

The lower milk fat content with barley fibre is consistent with other studies (Thomas et al. 1986, Huhtanen 1987 b, Huhtanen et al. 1988) where starchy and fibrous supplements

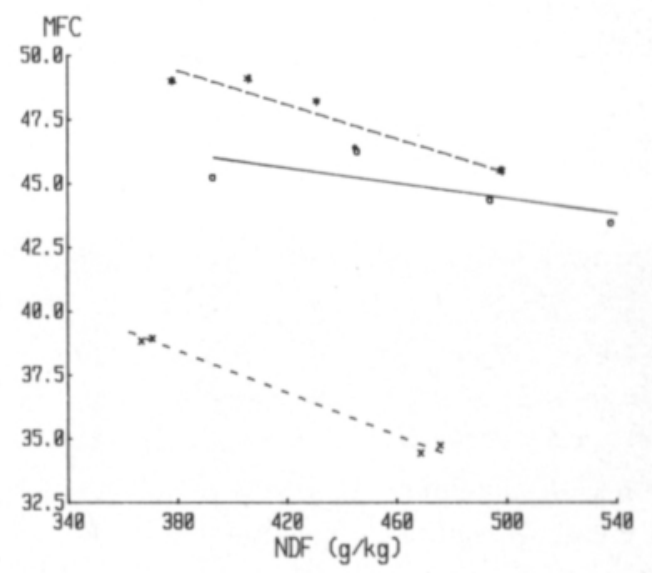

Fig. 1. The relation between dietary NDF content and milk fat concentration (MFC; $\mathrm{g} / \mathrm{kg}$ ) in cows given different carbohydrate supplements ( ${ }^{*}$ НUнтA. NEN 1987 a; O HUHTANEN et al. 1988; x present study).

were compared in cows given grass silage ad libitum with moderate levels of concentrate (ca. $400 \mathrm{~g} / \mathrm{kg}$ total DM intake). On the other hand, PHIPPs et al. (1987) reported a higher milk fat content with fibrous than with starchy concentrate. In their study, however, concentrate comprised a higher proportion of the total DM intake $(600 \mathrm{~g} / \mathrm{kg})$, and also the higher sugar content in fibrous concentrate than in starchy concentrate may have affected rumen fermentation and milk fat content. In all three studies (Huhtanen 1987 b, HuhtaNEN et al. 1988, present study) where fibrous by-products and barley with ad libitum silage have been compared, there has been a negative relationship between dietary NDF content and milk fat content (Fig. 1).

The decrease in milk protein content with barley fibre was much smaller than in the preceding study (HuHTANEN et al. 1988). The present results confirm the suggestion that lower milk protein content with $\mathrm{F}$ diets may also be related to the higher fat content of barley fibre (HUHTANEN et al. 1988), because the differences in concentrate intake were small in the present trial. This is in general agreement with the results of Tномаs et al. (1986), who found a lower milk protein content with fibrous concentrate than with barley- 
based concentrate when fat prills were included in the fibrous concentrate.

Higher efficiency of utilization of ME when the effect of live weight change was ignored is in agreement with the results of earlier studies where sugar beet pulp (HUHTANEN 1987 a) and barley fibre (HUHTANEN et al. 1988 ) were compared with barley in cows given silage ad libitum. This may reflect changes in energy partitioning between milk and body tissues as indicated by the higher live weight gain in cows given $\mathrm{B}$ diets than those given $\mathrm{F}$ diets in the present study, and higher plasma insulin concentration in cows given barley supplements than in those given sugar beet pulp (Miettinen and Huhtanen 1987). Sutton et al. (1987) reported a slightly higher value for milk energy/ME available for production with the fibrous concentrates than with starchy concentrates.

Higher efficiency with $\mathrm{F}$ diets than with $\mathrm{B}$ diets also when the effect of live weight change was included in the calculations suggests ei- ther a more efficient higher utilization of ME with $\mathrm{F}$ diets or that the energy values of live weight change were different for $\mathrm{F}$ and $\mathrm{B}$ diets.

The reasons for lower $k_{1}$ in cows given DDS supplements are uncertain, but may partly be accounted for by the energy cost of excreting the excess of $\mathrm{N}$ in urine (OLdHAM 1984) or errors in estimates of energy values of live weight change.

In conclusion, the results show that giving a supplement based on barley fibre results in higher yields of milk, milk protein and lactose than one based on barley, provided silage is given ad libitum. Further studies are needed to establish more 'clearly the reasons for the increased milk yield and changes in milk fat content. DDS had no effect on production response and on basis of the present results it can not be recommended for protein supplement in dairy cows given grass silage ad libitum.

\section{References}

ArC. (Agricultural Research Council). 1984. The Nutrient Requirements of Ruminant Livestock. Supplement No 1. The Commonwealth Agricultural Bureaux.

Chamberlain, D.G., Thomas, P.C., Wilson, W., New. Bold \& MacDonal.D, J.C. 1985. The effects of carbohydrate supplements on ruminal concentration of ammonia in animals given grass silage. J. agric Sci., Camb. 104: 47-58.

Castle, M.E., Gill, M.S. \& Watson, J.N. 1981. Silage and milk production: a comparison between barley and dried sugar-beet pulp as silage supplements. Grass and Forage Science 36: 319-324.

- Retter, W.C., Watson, J.N. \& Zewdie, E. 1977. Silage and milk production: a comparison between four rates of groundnut cake supplementation of silage of high digestibility. J. Br. Grassl. Soc. 32: 43-48.

Gordon, F.J. 1979. The effect of protein content of the supplement for dairy cows with access ad libitum to high digestibility, wilted grass silage. Anim. Prod. 28: 183-189.

Huhtanen, P. 1988. The effects of barley, unmolassed beet pulp and molasses supplements on organic matter, nitrogen and fibre digestion in the rumen of cattle given silage diet. Anim. Feed Sci. Technol. In press.

- 1987 a. The effect of dietary inclusion of barley, unmolassed sugar beet pulp and molasses on milk production, digestibility and digesta passage in dairy cows given silage based diet. J. Agric. Sci Finl. 59: 101-119.

$-1987 \mathrm{~b}$. The effect of carbohydrate supplements on the utilization of grass silage diets. pp. 1-45. Academic Dissertation. Department of Animal Husbandry, University of Helsinki SF-00710 Helsinki.

- Ala-SeppälÄ, H. \& NÃsi, M. 1988. Response of silage intake and milk production to replacement of barley by barley fibre delivered from integrated starch ethanol process. J. Agric. Sci Finl. 60: 711-721.

- NǍsı, M. 1988. Unpublished.

Kassem, M.M., Thomas, P.C., Chamberlain, D.G. \& RoBertSON, S. 1987. Silage intake and milk production in cows given barley supplements of reduced ruminal degradability. Grass and Forage Science 42: 175-183.

Klopfenstein, T. 1985. Distillers by-products backed by fourty years of research. In Distillers Feed Conference Proc. Vol 40: 8-19.

MAFF (Ministry of Agriculture, Fisheries and Food). 1975. Energy allowances and feeding systems for ruminants. Technical Bulletin 33. 79 p. London.

MAYne, C.S. \& Gordon, F.J. 1984. The effect of type of 
concentrate and level of concentrate feeding on milk production. Anim. Prod. 39: 65-75.

Miettinen, H. \& Huhtanen, P. 1987. Effect of the type of supplement on blood metabolites in dairy cows given grass silage ad libitum. Unpublished.

NÄsı, M. 1988. Evaluating barley feed fractions from integrated ethanol-starch production in diets of ruminants. J. Agric. Sci Finl. 60: 701-709.

Oldham, J.D. 1984. Protein-energy interrelationships in dairy cows. Dairy Sci 67: 1090-1114.

Phipps, R.H., Sutton, J.D., Weller, R.F. \& Bines, J.A. 1987. The effect of concentrate composition and method of silage feeding on intake and performance of lactating dairy cows. J. agric. Sci., Camb. 109: 337-343.

Rooke, J.A., Rymer, C., Maya, F.M. \& Armstrong, D.G. 1987. Comparative digestion of silage-based diets by sheep and cattle. In Eight Silage Conference Summary of Papers Sept. 1987. Pp. 157-158.

Setãlā, J., Syrjālä-Qvist, L., Poutiainen, E., Tuorı, M. \& RIIPINEN, U. 1984. Feeding of high producing dairy cows according to rumen unc.egradable protein requirements in grass silage based diet. J. Scient. Agric. Soc. Finl. 56: 73-82.

SloAn, B.K. \& Rowlinson, P. 1987. A note on concentrate energy source for dairy cows in mid lactation.

\section{SELOSTUS}

\section{Ohrarehun ja tärkkelysrankin vaikutus säilörehun syöntiin ja maitotuotokseen lypsylehmillä}

\author{
Pekka Huhtanen, Hannele Ala-Seppälä ja \\ Matti Näsi \\ Helsingin yliopisto, kotielaintieteen laitos, \\ $00710 \mathrm{Helsin} k \mathrm{i}$
}

Tutkimuksessa verrattiin integroidusta tärkkelys-etanoliprosessista saatavan ohrarehun ja ohran tuotantovaikutuksia sekă kuivatun tärkkelysrankin arvoa valkuaisrehuna vapaalla säilörehuruokinnalla. Koe-eläiminä oli 20 Fr-lehmää, jotka arvottiin 5:stä maitotuotoksen ja poikimisesta kuluneen ajan perusteella muodostetusta blokista neljäăn karsinaan. Koe tehtiin $4 \times 4$ latinalaisen neliön mukaan, joissa dieetit oli suunniteltu $2 \times 2$ faktoriaalisen koejärjestyksen mukaisesti. Koejäsenină olivat ohra (B), ohra + tärkkelysrankki (BD), ohrarehu (F) ja ohrarehu + tärkkelysrankki (FD). Väkirehuannos oli $7.5 \mathrm{~kg}$ kuiva-ainetta päivăssä, joista D-ruokinnoilla $0.9 \mathrm{~kg}$ korvattiin tärkkelysrankilla.
Anim. Prod. 45: 321-323

Snedecor, G.W. \& Cochran, W.C. 1967. Statistical methods. 6th Ed. 593 p. The Iowa State Univ. Press. Ames, USA.

Sutton, J.D., Bines, J.A., Morant, S.V., Napper, D.J. \& Givens, D.I. 1987. A comparison of starchy and fibrous concentrates for milk production, energy utilization and hay intake by Friesian cows. J. agric. Sci., Camb. 109: 375-386.

Thomas, C., Aston, K., Daley, S.R. \& Bass, J. 1986. Milk production from silage. 4 . The effect of the composition of the supplement. Anim. Prod. 42: 315-325.

- Aston, K., Tayler, J.C., Daley, S.R. \& Osbourn, D.F. 1981. Milk production from silage. I. The influence of an additive containing formaldehyde and formic acid on the response of lactating heifers and cows to supplementary protein. Anim. Prod. 32: 285-295.

Thomas, P.C. \& Chamberlain, D.G. 1984. Manipulation of milk composition to meet market needs. Recent Advances in Animal Nutrition 1984. (Ed. Haresign, W. \& Cole, D.J.A.). Pp. 219-243. Butterworths.

Tyrrel, H.F. \& Reid, J.T. 1965. Prediction of energy value of cows milk. J. Dairy Sci. 48: 1215-1223.

Ms received
Ohrarehua saaneet lehmät söivăt $0.38 \mathrm{~kg} / \mathrm{pv}(\mathrm{P}<0.05)$ enemmän săilörehun kuiva-ainetta (ka) kuin ohraa saaneet, mutta ka:n kokonaissyönnissă ei ollut eroa.

Maitotuotos oli $2.2 \mathrm{~kg} / \mathrm{pv}(\mathrm{P}<0.001)$ suurempi F-ruokinnoilla kuin B-ruokinnoilla. Korkeamman (39.0 v. $34.5 \mathrm{~g} / \mathrm{kg} ; \mathrm{P}<0.001)$ maidon rasvapitoisuuden johdosta rasvatuotos oli B-ruokinnoilla hieman suurempi (805 v. $787 \mathrm{~g} / \mathrm{pv} ; \mathrm{P}<0.1)$. Maidon valkuaispitoisuus oli F-ruokinnoilla alempi $(\mathrm{P}<0.05)$ kuin B-ruokinnoilla, mutta suuremman maitotuotoksen johdosta valkuaistuotos oli F-ruokinnoilla $8.3 \%(\mathrm{P}<0.001)$ suurempi kuin B-ruokinnoilla. Ohran korvaaminen ohrarehulla lisäsi maidon laktoosipitoisuutta $(\mathrm{P}<0.05)$ ja laktoosituotos- 
ta $(\mathrm{P}<0.001)$. Ohraa saaneiden lehmien elopainon lisäys oli suurempi $(\mathrm{P}<0.05)$ kuin ohrarehua saaneiden.

Tärkkelysrankilla ei ollut vaikutusta säilörehun syőntiin, maitotuotokseen tai maidon koostumukseen. Elopainon lisăys oli rankkia saaneilla lehmillä pienempi $(\mathrm{P}<0.01)$.

Maidon energian tuotos oli $\mathrm{F}$ ruokinnoilla suurempi $(\mathrm{P}<0.05)$ kuin B-ruokinnoilla huolimatta siitä, ettă maidontuotantoon käytettăvissă olevan muuntokelpoisen energian (ME) măără oli F-ruokinnoilla pienempi. Tămă osoittaa, ettă ohrarehua saaneet lehmät käyttivăt suuremman osan saamastaan energiasta maidontuotantoon ku- dosvarastojen kasvattamisen sijasta. Laskennallisesti ME:n hyvăksikăyttö maidontuotantoon oli F-ruokinnoilla parempi kuin B-ruokinnoilla sekă otettaessa elopainon muutos huomioon ettă jătettăessă se huomioonottamatta laskelmissa.

Tulokset osoittavat, että korvattaessa vapaalla säilörehuruokinnalla ohra ohramelassia sisăltävällä ohrarehulla maito- ja valkuaistuotos lisaaăntyvăt ja rasvatuotos pysyy ennallaan. Tulokset osoittivat lisăksi, ettă lampailla määritetyn rehuarvon ( $15 \%$ huonompi kuin ohran) ja lypsylehmillä todetun tuotantovaikutuksen välillä oli selvä ristiriita. 